\title{
The Concept of Penal Mediation for the Crime of Medical Negligence in Realizing Legal Protection for Medical Personnel and Patients or Their Families
}

\author{
Rudy Sapoelete; Muhadar; Otto Yudianto; Budiarsih \\ Faculty of Law, Universitas 17 Agustus 1945 Surabaya, Indonesia \\ http://dx.doi.org/10.18415/ijmmu.v8i2.2406
}

\begin{abstract}
The research objective was to determine the form of legal protection for medical personnel and patients or their families for criminal acts of medical negligence and the form of the mediation concept of penalties for medical negligence. This research uses normative juridical legal research, is descriptive analysis, data sources are primary and secondary legal materials. Medical negligence lies between deliberate and coincidence, the crime of medical negligence is not mens rea, culpa offense is a false offense. The concept of penal mediation for the criminal act of medical negligence is to bring together medical personnel with patients or their families directly, changing the perspective of criminal law towards a humanistic criminal law, because the main focus isn't on retaliation but on efforts to restore and make peace. The concept of penal mediation isn't intended to maintain discretionary measures by law enforcers but to provide a place for penal mediation for criminal acts of medical negligence in the criminal justice system in realizing legal protection for medical personnel and patients or their families. The concept of penal mediation in realizing legal protection for medical personnel and patients or their families is a reform of criminal law as a reflection of restorative justice that needs to be regulated and by offering conditional norms. Criminal law reform must be carried out by reviewing and reconstructing criminal law in accordance with the social central values and socio-cultural values of the Indonesian people so that Indonesia's criminal law in the future is filled with Pancasila values.
\end{abstract}

Keywords: Legal Protection; Penal Mediation; Medical Negligence Crime

\section{Introduction}

Laws are formed and enforced as a means to provide protection for every citizen in an equitable manner. Criminal law is a specific area in the Indonesian legal system which functions to provide protection for the rights and interests of individuals, including the rights and interests of perpetrators and victims of criminal acts. This opinion is in accordance with Law No. 29/2004 concerning Medical Practice, which is also designed to provide protection and legal certainty to health service providers and recipients.

The relationship between medical personnel and patients as in the law is a relationship in an effort to heal. But every failure in these efforts, generally the community calls it medical malpractice. Medical 
malpractice is different from medical negligence, in that medical malpractice is an act carried out consciously, has a motive or purpose to cause a result that occurs, deliberately and causes harm, whereas medical negligence is between intentional and accidental, where it's done carelessly/guesswork, there is no motive or there is no goal to be achieved.(1)

In the case of Dewi Ayu (2010) at the Kandow Manado General Hospital, there was a significant difference of opinion in legal considerations regarding the elements of medical crime. In ordinary criminal acts the focus is the result (gevolg), while in a medical crime, it is not the result but the cause. The application of the element of medical negligence as stipulated in Article 359 of the Criminal Code isn't easy to do, this is because not all consequences of medical action occur due to medical negligence, it can also result from medical risks that must be borne by the patient or his family. Cassation Decision No.365/K/Pid/2012 Dewi Ayu case was found legally and convincingly proven guilty of committing a crime as referred to in Article 359 of the Criminal Code jo. Article 361 Criminal Code jo. Article 55 paragraph (1) of the Criminal Code in carrying out the Cito Seciocesaria operation resulting in an emboli that caused $\mathrm{S}$ to die and sentenced Dewi Ayu to ten months imprisonment. Then in the Judgment of Judgment by the Supreme Court Dewi Ayu was declared free for the sake of law, even though in the Cassation Judgment, Dewi Ayu was found guilty and convinced of negligence (vide Article 359 of the Criminal Code jo. Passal 361 jo conjunction with Article 55 of the Criminal Code) by imprisonment of ten months each.

The difference of opinion on the legal considerations and the decision caused losses to the parties, medical personnel have received legal certainty but didn't get legal benefits, while patients didn't get justice and legal benefits. Without sacrificing the achievement of legal objectives, the case should be able to mediate efforts to achieve social harmony, which can provide legal protection for medical personnel and patients or their families. The originality of this study compares with the resolution of medical disputes between doctors and patients as stipulated in Article 50 of Law No. 29/2004 concerning Medical Practice and Article 57 of the Criminal Procedure Code as a reference, this is due to Law No. 29/2004 concerning Medical Practice doesn't regulate how to proceed if there is an allegation that a doctor has violated the articles in Law no. 29/2004 concerning Medical Practice.(2) The formulation of the problem raised is how is the legal protection of medical personnel and patients or their families for the crime of medical negligence? And what is the concept of penal mediation for medical negligence?

\section{Research Methods}

This type of research uses normative juridical legal research, is descriptive analysis, data sources are primary and secondary legal materials, data analysis method use qualitative methods with deductive thinking.(3)

\section{Research Results and Discussion}

\section{Legal Protection of Medical Personnel and Patients or their Families for Crimes of Medical Negligence}

The Indonesian nation as in the Preamble of the Constitution has the goal of protecting the entire Indonesian nation.(4) As a country based on the welfare state, it also regulates the needs of the community for the right to health. In the beginning, health development was in the form of efforts to cure diseases, then developed towards integrated health efforts that included comprehensive, integrated and continuous efforts, not only with the application of science and technology, but also in conjunction with the application of social, ethical, disciplined and legal values. 
Human rights are basic rights that are owned by humans from birth and are gifts that must be respected, upheld and protected for the sake of human honor. Legal protection is a guarantee provided by the state to legal subjects in accordance with the rule of law, both preventive and coercive in nature which are stipulated in writing / unwritten in order to enforce the law.(5)

The relationship between doctor and patient, or better known as therapeutic transactions, was born because of the vertical relationship between medical personnel and patients that has positive and negative impacts.(6) The object of the transaction is not the patient's recovery but rather to determine and seek the most appropriate healing efforts for the patient's recovery. The therapeutic transaction will turn into a medical dispute if the patient is dissatisfied with medical personnel in an effort to heal. Legal protection of medical personnel and patients or their families in therapeutic transactions can occur:(7)

1. The relationship between medical personnel and patients or their families of medical personnel and patients or their families is due to a contract. Basically, medical practice is the provision of individual assistance by medical personnel to patients in the form of medical services. Patients come to medical personnel to take advantage of the available medical services, so there is a relationship between medical personnel and patients called therapeutic transactions. The relationship between medical personnel and patients is a contractual relationship that doesn't promise a cure or death, but in the context of a healing effort, which is commonly known as verbal inspection / inspanningsverbintenis, which requires rights and obligations between medical personnel and patients, and creates legal responsibility for each.

\section{Relationship between medical personnel and patients or their families due to law (zaakwarneming)}

So far, the settlement of cases of criminal medical negligence has a fundamental weakness, namely neglecting the rights of patients as victims. In the Criminal Procedure Code and Law no. 29/2004 concerning Medical Practice and other related laws, there are very few articles that discuss patients as victims. The patient's position as a victim doesn't have a place in the criminal justice system (retributive justice), because it's only intended to impose sanctions on medical personnel as perpetrators without considering the aspects suffered by the patient or his family as victims. However, restorative justice has developed in various countries, affecting the criminal law system in Indonesia, which has shifted the concept of punishment from retributive justice to restorative justice, thus bringing bright hope in providing legal protection for medical personnel and patients or their families for the crime of medical negligence. Restorative justice doesn't only present medical personnel as perpetrators in the criminal justice system but also involves the role of patients as victims or their families.(8) Medical personnel as perpetrators of criminal acts of medical negligence are restored through the criminal justice system so as to encourage peace between patients or their families and medical personnel, in the end the legal protection of medical personnel and patients or their families can be realized. The peace is carried out through penal mediation, for example paying compensation for the suffering suffered by the patient or his family.

Hope for restorative justice, when there is a letter from the National Police Chief No. B/3022/XII/2009/SDEOPS regarding Case Subscription through Alternative Dispute Resolution, Chief of Police Circular No.SE/8/VII/2018 concerning the Application of Restorative Justice in Criminal Case Settlement, National Police Regulation No. 6/2019 concerning Criminal Investigation and Prosecutor's Regulation No. 15/2020 concerning Cessation of Prosecution Under Restorative Justice.

Analyze and understand the Kapolri Letter and Regulations compared to the concept of restorative justice, that the Kapolri Letter and these Regulations aren't sufficient to provide protection for medical personnel and patients or their families and to restore medical personnel and patients because the Kapolri Letter and the Regulations only regulate One material only from restorative justice, namely 
recovery of patients as victims, hasn't explained the recovery process which is the ultimate goal of restorative justice but still places patients as objects and doesn't place patients as victims to participate in the criminal justice system.

\section{The Concept of Penal Mediation for the Crime of Medical Negligence}

Medical malpractice is different from medical negligence, in that medical malpractice(9) is an act carried out consciously, has a motive or purpose to cause a result that occurs, is done intentionally and causes harm whereas medical negligence is between intentional and accidental, done carelessly is not there is a motive or there is no goal to be achieved.(10) There are two ways to settle medical crimes, namely litigation and non-litigation. The general public view is that medical crimes are better resolved through litigation, but to achieve proof isn't easy, when a patient cannot prove a medical error, the case ends at the time of proof.(11) The concept of penal mediation for the crime of medical negligence doesn't maintain discretionary measures by law enforcement officials but provides a place for penal mediation for criminal acts of medical negligence in the criminal justice system. The concept of penal mediation is used to overcome rigidity in the applicable criminal justice process, avoiding the negative effects of the purpose of punishment according to current retributive theories.(12)

The basic principle of the penal mediation concept for the crime of medical negligence finds a basis that upholds the value of balance and benefit both to medical personnel and patients or their families.(13) There are many things that need to be reconstructed in the criminal justice system in Indonesia, not all criminal cases have to end up in court, especially the crime of medical negligence, in which both medical personnel and patients or their families can still be restored so that conditions that have been damaged can be repaired again and efforts arise win-win solution according to the penal mediation paradigm. The concept of penal mediation for the criminal act of medical negligence for medical personnel as perpetrators can eliminate the negative stigma of society against medical personnel, because after being from the correctional institution it's possible that it will be difficult to improve the honor of the profession that is carried and him to continue his life as before.

The concept of penal mediation in realizing legal protection for medical personnel and patients or their families is a reform of criminal law as a reflection of restorative justice that needs to be regulated and by offering norms of requirements, namely:

1) There is an agreement between the patient or his family and medical personnel.

2) Caused by medical negligence, not medical intent.

3) There is a loss for the patient or his family (disabled or dead).

4) The threat of criminal sanctions of less than 5 years.

5) Not a repeat medical crime.

6) Has meet professional standards, medical service standards and standard operating procedures.(14)

Criminal law reform must be carried out by reviewing and reconstructing criminal law in accordance with the social central values and socio-cultural values of the Indonesian people so that Indonesia's criminal law in the future is filled with Pancasila values.

\section{Conclusion}

Legal protection for medical personnel and patients or their families in therapeutic transactions can occur due to two things, namely a relationship due to a contract (therapeutic) and a relationship due to law (zaakwarneming). The Chief of Police's Letter and Regulations are not sufficient to provide protection for medical personnel and patients or their families as well as to restore medical personnel and 
patients because it only regulates one material of restorative justice, namely recovery of patients as victims, but still puts patients as objects and does not place patients as objects. victims to participate in the criminal justice system.

\section{References}

1. Fitriono RA, Setyanto B, Ginting R. PENEGAKAN HUKUM MALPRAKTIK MELALUI PENDEKATAN MEDIASI PENAL. Yust J Huk. 2016;

2. Trisnadi S. PERLINDUNGAN HUKUM PROFESI DOKTER DALAM PENYELESAIAN SENGKETA MEDIS. J Pembaharuan Huk. 2017;

3. Michael T. Kesulitan Dalam Memaknai Kesempurnaan Informasi Era Covid-19. Adalah Bul Huk dan Keadilan. 2020;

4. MPR. Undang-Undang Dasar Negara Republik Indonesia Tahun 1945: Amandemen ke IV. Jaringan Dokumentasi dan Informasi Hukum. 2002.

5. Michael T. RIGHT TO HAVE RIGHTS. Mimb Keadilan [Internet]. 2017 Feb 1;106. Available from: http://jurnal.untag-sby.ac.id/index.php/mimbarkeadilan/article/view/2203

6. Mannas YA. Hubungan Hukum Dokter dan Pasien Serta Tanggung Jawab Dokter Dalam Penyelenggaraan Pelayanan Kesehatan. J CITA Huk. 2018;

7. ANALISIS HUKUM KONTRAK TERAPEUTIK TERHADAP TINDAKAN MEDIK DALAM HUBUNGAN PASIEN DENGAN DOKTER DI RUMAH SAKIT. LEX Soc. 2016;

8. Setyorini EH, Sumiati S, Utomo P. KONSEP KEADILAN RESTORATIF BAGI ANAK YANG BERKONFLIK DENGAN HUKUM DALAM SISTEM PERADILAN PIDANA ANAK. DiH J Ilmu Huk. 2020;

9. PERTANGGUNGJAWABAN PIDANA TINDAKAN MALPRAKTEK KEDOKTERAN DALAM KAITANNYA DENGAN MASALAH PEMBUKTIAN. LEX Crim. 2019;

10. Avraham R, Schanzenbach MM. Medical malpractice. In: The Oxford Handbook of Law and Economics: Volume 2: Private and Commercial Law. 2017.

11. Mayasari DE. Perlindungan Hak Anak Kategori Juvenile Delinquency. Kanun J Ilmu Huk. 2018;

12. Harefa B. MEDIASI PENAL SEBAGAI BENTUK DIVERSI DALAM PENYELESAIAN PERKARA PIDANA ANAK BERBASIS KEADILAN RESTORATIF. J Komun Huk. 2018;

13. Ranjan S. Domestic Violence Legislation in Greece: Analysis of Penal Mediation. Women Crim Justice. 2020;

14. Oyebode F. Clinical errors and medical negligence. Medical Principles and Practice. 2013.

\section{Copyrights}

Copyright for this article is retained by the author(s), with first publication rights granted to the journal.

This is an open-access article distributed under the terms and conditions of the Creative Commons Attribution license (http://creativecommons.org/licenses/by/4.0/). 